\title{
Eruption style at Kīlauea Volcano in Hawai i i linked to primary melt composition
}

\author{
I. R. Sides, M. Edmonds`, J. Maclennan, D. A. Swanson and B. F. Houghton
}

\begin{abstract}
Explosive eruptions at basaltic volcanoes have been linked to gas segregation from magmas at shallow depths in the crust. The composition of primary melts formed at greater depths is thought to have little influence on eruptive style. Primary melts formed at ocean island basaltic volcanoes are probably geochemically diverse because they are often associated with melting of a heterogeneous plume source in the mantle. This heterogeneous primary melt composition, and particularly the content of volatile gases, will profoundly influence magma buoyancy, storage and eruption style. Here we analyse the geochemistry of a suite of melt inclusions from 25 historical eruptions at the ocean island volcano of Killauea, Hawai'i, over the past 600 years. We find that more explosive styles of eruption at Kilauea Volcano are associated statistically with more geochemically enriched primary melts that have higher volatile concentrations. These enriched melts ascend faster and retain their primary nature, undergoing little interaction with the magma reservoir at the volcano's summit. We conclude that the eruption style and magma-supply rate at Kīlauea are fundamentally linked to the geochemistry of the primary melts formed deep below the volcano. Magmas might therefore be predisposed towards explosivity right at the point of formation in their mantle source region.
\end{abstract}

E ruption style at basaltic volcanoes such as Kilauea has been up to now linked primarily to shallow changes in magma ascent rate $^{1}$ and gas flux ${ }^{2}$, which determine whether the eruption is effusive or explosive (Hawaiian-fountaining or Strombolian) in character. There is growing evidence, however, that the mantle source, and hence the melts generated beneath Kilauea Volcano, are geochemically heterogeneous on small spatial scales $^{3-5}$ and distinct from any plume-scale geochemical zonation ${ }^{6-8}$, and that mantle heterogeneity may influence the extent of melting, magma supply rate and eruption style ${ }^{3,4}$. The concentrations of volatile elements in primary melts, like other incompatible trace elements, vary according to the source composition and the degree of mantle melting ${ }^{6,9}$. Relatively 'enriched' melts, with higher volatile concentrations and buoyancy, may ascend faster than more 'depleted' melts ${ }^{10}$. These differences in ascent velocity may control magmatic pathways and evolution, leading the more enriched melts to carry more exsolved volatiles to low pressures, thus increasing the likelihood of explosive styles of volcanism. This study tests the hypothesis relating eruption style to pre-eruptive melt composition by examining the geochemistry of olivine-hosted melt inclusions (Methods) found in the products of 25 eruptions, classified by eruption style (Table 1), that have taken place over the past 600 years at the summit and upper rift zones of Kilauea Volcano (see Supplementary Data for a table describing the eruptions, data sources and deposit types; Fig. 1). The eruptions and deposits were classified according to the detailed scheme in Table 1, binned into effusive, high fountain, fissure and 'transient explosive', an eruption class that includes gas-rich, melt-poor explosions.

\section{Olivine and melt inclusion geochemistry}

Olivine core compositions range from 77.5 to $89.2 \mathrm{~mol} \%$ forsterite (Fo), shown as a function of the carrier glass $\mathrm{Mg \#}$ on a Rhodes plot in Fig. 2a. All eruption types produce olivines and matrix glasses with a wide range of compositions, although the highest
Fo and Mg\# values are associated with high-fountaining eruptions and the lowest with effusive eruptions. In general, the effusive and transient explosive eruptions are closest to equilibrium with their carrier melts. The poor correlation between the host olivines and their average carrier melt compositions indicates a high degree of crystal-melt disequilibrium. The moderate $\mathrm{CaO}$ contents of the olivines $(0.18-0.35 \mathrm{wt} \%)$ suggest that they are magmatic ${ }^{4}$ but they are, in general, too forsteritic to be in equilibrium with their carrier liquid, indicating that they may have been entrained from mush that crystallized from more primitive melts ${ }^{11}$. Preservation of chemical disequilibrium requires that the olivines were held in the carrier melt for a timescale that was short compared with that for diffusional equilibration ${ }^{12}$. Most of the eruption samples track the $1: 1$ correspondence line between average melt inclusion $\mathrm{La} / \mathrm{Yb}$ ratios versus the $\mathrm{La} / \mathrm{Yb}$ of the matrix glasses for each eruption, implying that the inclusion populations reflect the pre-eruptive melt composition (Fig. 2b). However, a number of samples do not; of these, most belong to high-fountaining and fissure eruptions. These melts may have encountered stored magmas during ascent, which resulted in heterogeneous carrier melts.

The post-entrapment crystallization (PEC)-corrected melt inclusions have $6.41-14.7 \mathrm{wt} \% \mathrm{MgO}$ and the matrix glasses $4.27-$ $10.3 \mathrm{wt} \% \mathrm{MgO}$ (Supplementary Fig. 1 and see Supplementary Methods for details of the PEC correction procedure). There is significant variation in minor and trace elements (outside the uncertainty associated with either analytical error or the PEC corrections) at constant forsterite content (Supplementary Fig. 2). Trace element concentrations in the matrix glasses and melt inclusions exhibit substantial variation both within and between individual eruptions. The inclusions erupted during high fountaining exhibit a broader range in minor and trace element compositions than the other groups (Supplementary Figs 2 and 3). These large variations are seen for all elements and throughout all eruption style categories. 


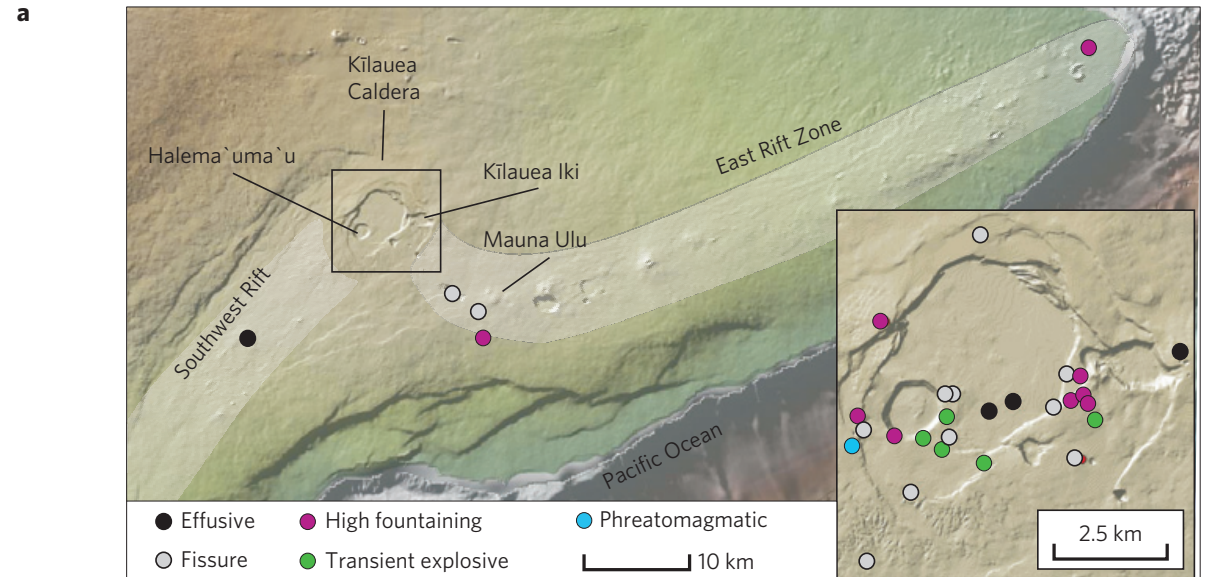

b

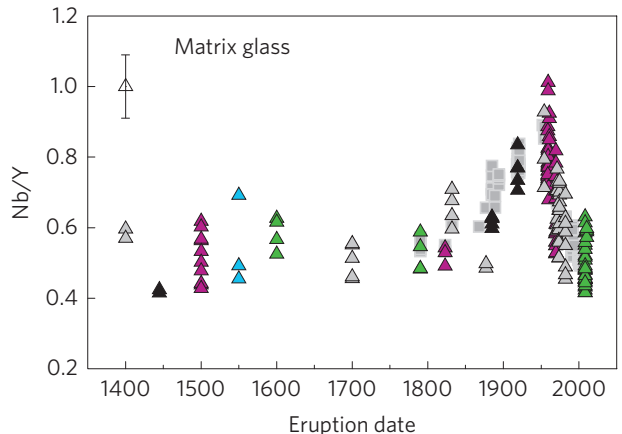

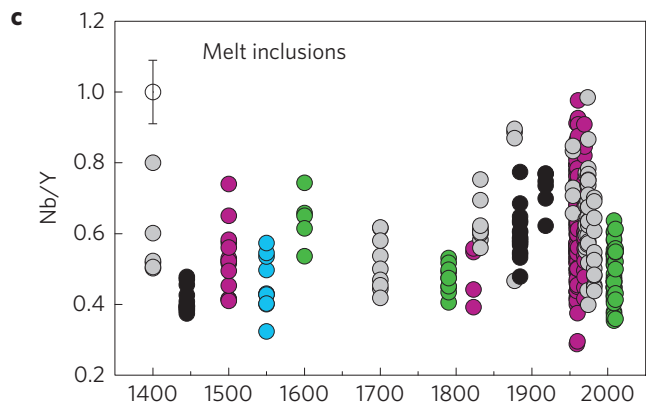

Figure 1 Spatial and temporal context of the study. a-c, Overview map with sample locations and key to eruptive type (a); time series of Nb/Y in matrix glasses (b) and $\mathrm{Nb} / \mathrm{Y}$ in melt inclusions (c). Open symbols and error bars in $\mathbf{b}$ and $\mathbf{c}$ indicate analytical uncertainty. See Supplementary Data for microanalytical methods.

Table 1 | Description of the eruptions and deposits within each eruption class.

\begin{tabular}{|c|c|c|}
\hline Style & Eruption description & Sample description \\
\hline Effusive & Lava flows, no explosive component & $\begin{array}{l}\text { Upper } 1-1.5 \mathrm{~cm} \text { of the glass-rich vesicular rope texture on pāhoehoe lava flow } \\
\text { surfaces. }\end{array}$ \\
\hline $\begin{array}{l}\text { Fissure/weak } \\
\text { fountain }\end{array}$ & $\begin{array}{l}\text { Low }(<50 \mathrm{~m} \text { ) linear arrays of fountains, } \\
\text { forming spatter ramparts }\end{array}$ & $\begin{array}{l}\text { A spectrum of highly vesicular to dense scoria clasts. Scoria clasts typically } \\
\text { fragments } 2-3 \mathrm{~cm} \text { with a fluidal, smooth exterior of dense glass and an inner } \\
\text { vesicular ( } 70-85 \% \text { vol\%) core. Vesicles generally spherical, up to } 0.5 \mathrm{~cm} \\
\text { diameter, with relatively thick walls. }\end{array}$ \\
\hline High fountain & Point source fountains $50-600 \mathrm{~m}$ in height & $\begin{array}{l}\text { Some deposits rich in achneliths and pumice clasts with fluidal surfaces and } \\
\text { highly vesicular interiors; others with ragged, highly vesicular golden pumice and } \\
\text { reticulite with up to } 98 \% \text { vesicularity. The highest fountains produced spatter } \\
\text { bombs up to } 25 \mathrm{~cm} \text { in diameter. }\end{array}$ \\
\hline $\begin{array}{l}\text { Transient } \\
\text { explosive }\end{array}$ & Gas-rich, melt-poor explosions & $\begin{array}{l}\text { Mixture of lithic and juvenile material including lithic blocks, lapilli and ash, Pele's } \\
\text { hair and tears, and juvenile bombs up to } 20 \mathrm{~cm} \text { diameter. The bombs are discrete } \\
\text { globules of vesicle-rich spatter and pumice, angular chunks of fresh and oxidized } \\
\text { scoria and glass-coated lapilli. }\end{array}$ \\
\hline Phreatomagmatic & $\begin{array}{l}\text { Ash-rich explosive eruptions caused by } \\
\text { interaction of magma with groundwater }\end{array}$ & $\begin{array}{l}\text { Mixtures of juvenile and lithic components, ranging from well-sorted fine ash, } \\
\text { loose crystals and lapilli to scattered large blocks up to } 1 \mathrm{~m} \text {. Fluidal clasts absent. } \\
\text { Most lapilli-sized particles were microcrystalline and bounded by fractured } \\
\text { surfaces; rare pristine glass. }\end{array}$ \\
\hline
\end{tabular}

The melt inclusions and matrix glasses contain 0.07-0.68 wt\% $\mathrm{H}_{2} \mathrm{O}$ and from below detection to 656 p.p.m. $\mathrm{CO}_{2}$, in broad accordance with previous studies ${ }^{13-16}$ (Fig. 3a). The melt inclusions equilibrated at $<1.5 \mathrm{kbar}$ (refs 17) if the melts were vapoursaturated (Fig. 3a). There are significant differences in the volatile concentrations of pre-eruptive melts associated with different eruption styles, with the largest range in volatile concentrations in the high-fountaining and fissure products. Effusive and transient explosive melt inclusions have generally lower $\mathrm{H}_{2} \mathrm{O}$ and $\mathrm{CO}_{2}$ concentrations. The melt inclusions associated with effusive eruptions have a narrow range of $\mathrm{H}_{2} \mathrm{O}$ contents, $<0.15 \mathrm{wt} \%$, but contain two inclusions with very high $\mathrm{CO}_{2}$. The $\mathrm{H}_{2} \mathrm{O}$ concentrations of the Ló 'ihi melts are generally higher than most Kỉlauea inclusions, ranging from 0.62 to $0.77 \mathrm{wt} \% \mathrm{H}_{2} \mathrm{O}$, and $\mathrm{CO}_{2}$ varies from below 
a

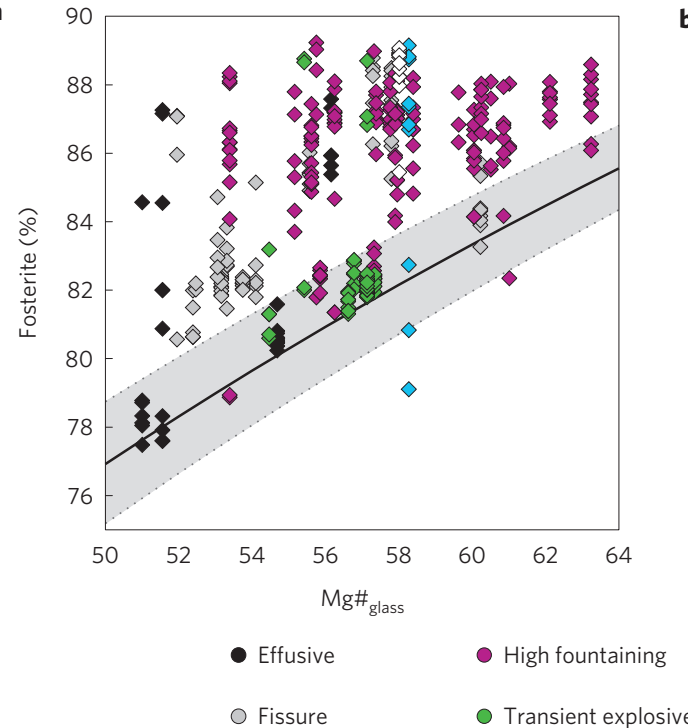

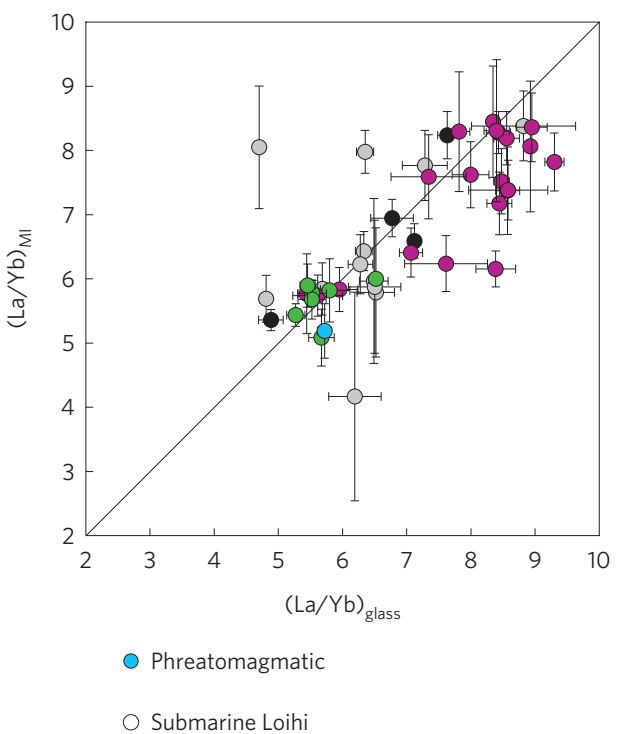

Figure 2 | Compositional relationship between melt inclusions, host olivines and carrier liquids. a, Rhodes plot of Fo content against host Mg\#. b, Mean $\mathrm{La} / \mathrm{Yb}$ of the melt inclusions against $\mathrm{La} / \mathrm{Yb}$ of the matrix glasses.

detection to 479 p.p.m. $\mathrm{CO}_{2}$ (Fig. 3a). Sulphur concentrations are $107-1,791$ p.p.m. in the inclusions and $35-1,459$ p.p.m. in the matrix glasses, although most matrix glasses have $<400$ p.p.m. S (Supplementary Fig. 4), similar to previously reported ${ }^{6,16,18,19}$. Chlorine $(\mathrm{Cl})$ and fluorine $(\mathrm{F})$ concentrations are 62-1,108 p.p.m. and 176-807 p.p.m. respectively in the melt inclusions, and 51-301 p.p.m. and 97-1,012 p.p.m. respectively in the subaerial matrix glasses (Supplementary Fig. 4), comparable to halogen concentrations previously recorded for Kilauea ${ }^{5,16,20,21}$. The $\mathrm{Cl}$ and F concentrations do not correlate with non-volatile incompatible elements such as La or with other volatile elements (Supplementary Fig. 4). $\mathrm{Cl} / \mathrm{K}_{2} \mathrm{O}$ values are mostly less than 0.036 (Supplementary Data), and there is no evidence for subvolcanic contamination by sea water ${ }^{21}$. High-fountaining products have the greatest range of $\mathrm{Cl}$ and $\mathrm{F}$ concentrations.

Unlike whole-rock compositions, melt inclusion compositions are unaffected by crystal accumulation and their geochemistry records melt differentiation and degassing before eruption. The large range of incompatible minor and trace element abundances at constant Fo content of olivine may be explained by the mixing of geochemically heterogeneous melts that formed as a result of variations in the source composition or partial melting process ${ }^{22-24}$. The more homogeneous compositions of the matrix glass samples are consistent with the complete mixing of these melts in the reservoir before each eruption.

\section{Statistical geochemical differences between eruption styles}

To determine whether the apparent geochemical differences between the eruption groups are significant, the KolmogorovSmirnov (KS) test (Supplementary Methods) is used. The analyses in each eruption population are plotted on cumulative histograms (Fig. 3). The KS test uses the maximum offset in cumulative percentage at a given concentration (the KS statistic, $D$ ) to ascertain whether sets of melt inclusions are drawn from the same underlying population (Supplementary Fig. 5). The $P$ values (Supplementary Table 4) reflect the significance of the difference; when $P$ is < 0.05 , the null hypothesis (that there is no difference between the populations) can be rejected at the $>95 \%$ confidence level. The KS statistics for the comparison between the effusive and high-fountaining styles of eruption are shown in Fig. 3, and the full set of statistics is given in Supplementary Data. In terms of $\mathrm{CO}_{2}$ concentrations, the statistics show that there are significant differences between the high-fountaining eruptions and both the effusive and transient explosive eruptions, with $D>26 \%$ and $P<$ $2 \%$. For $\mathrm{Nb} / \mathrm{Y}$, the statistics confirm significant differences between all eruption styles, aside from between fissure and high-fountaining eruptions, which are similar. For Fo content, the statistics show highly significant differences between all of the eruption styles $(D>$ $35 \%$ and $P<0.1 \%)$. The data confirm that different eruption styles at Kilauea are associated with significantly different pre-eruptive melt geochemical signatures, with more than $95 \%$ certainty that each group is sampling different underlying populations.

Melt inclusions associated with high-fountaining eruptions, which includes products from the earliest Keanākako'i eruption about 1500, the 1820-1823 Golden Pumice, the 1959 Kilauea Iki, the 1960 Kapoho and the 1969 Mauna Ulu eruption, have distributions with higher preserved concentrations of $\mathrm{CO}_{2}$ (Fig. 3b) than those inclusions from either effusive activity or transient explosive explosions, perhaps indicating that they equilibrated deeper in the system before eruption ${ }^{25}$ or that the melt inclusions experienced less PEC (ref. 26). The melt inclusions from fountaining and fissure eruption samples also have higher $\mathrm{H}_{2} \mathrm{O}$ concentrations (Fig. 3a), although it is almost certain that the effusive, and to some extent the explosively erupted melt inclusions, lost $\mathrm{H}^{+}$ owing to diffusion during eruption and flow ${ }^{27,28}$. High-fountain and fissure eruption melts are significantly more enriched in highly incompatible light rare earth elements than melts associated with other eruption types (Fig. 3c). The higher $\mathrm{Nb} / \mathrm{Y}$ of these eruption styles strongly implies that their primary melts are also richer in $\mathrm{CO}_{2}$ and other volatiles ${ }^{29}$, which is consistent with deeper saturation and higher ascent rates from depth ${ }^{30}$. Melt inclusions in the highfountain category are hosted in the most Fo-rich olivine populations (Fig. 3d), indicating that the pre-eruptive melts are more primitive than those of other styles, including the fissure events.

\section{Explosive eruptions fed by enriched, volatile-rich melts}

A picture of the geochemical control on eruption style emerges. Hot, primitive, enriched melts ascend rapidly from depth owing to the enhanced buoyancy imparted by their higher volatile contents, they may bypass the summit magma reservoir and erupt explosively as high fountains (owing to their high exsolved gas content and ascent 

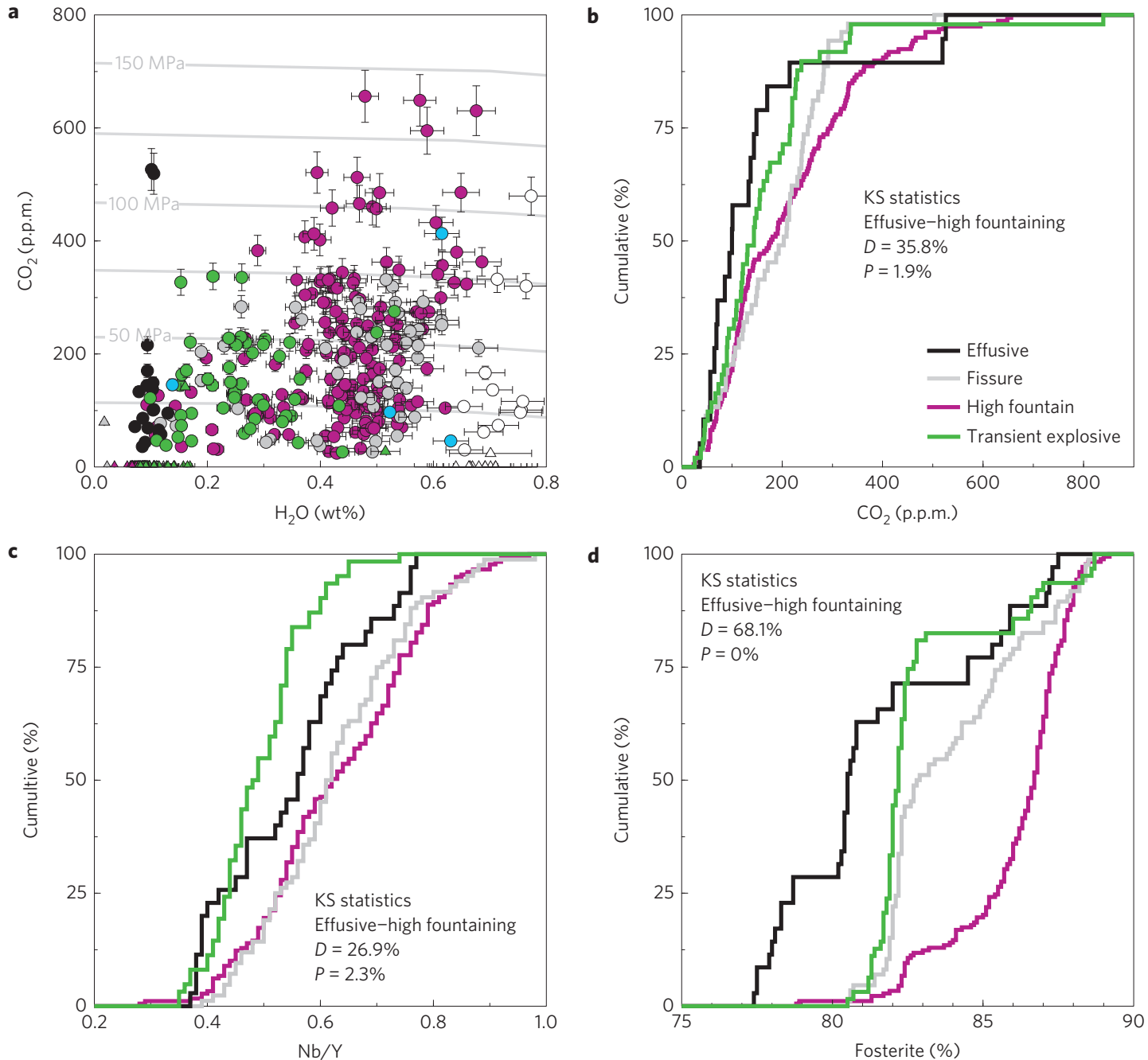

Figure 3 | Variations in melt inclusion compositions between different eruptive styles. $\mathbf{a}, \mathrm{CO}_{2}$ versus $\mathrm{H}_{2} \mathrm{O}$ (isobars from ref. 17). b, Cumulative histogram of $\mathrm{CO}_{2}$ concentrations. c, Cumulative histogram of $\mathrm{Nb} / \mathrm{Y}$. d, Cumulative histogram of Fo content of olivine hosts. The KS statistics for the pair of distributions 'effusive' and 'high fountaining' eruptions are shown (see Supplementary Data for a full description of the statistical test). Colour-coded for eruption style, see legend.

rate) just outside the margins of the caldera. More geochemically depleted melts (with lower volatile contents) ascend more slowly and intersect bodies of stored melts, stall, fractionate, degas and homogenize, before erupting in an effusive, or transient explosive style (Fig. 4). The depleted melts may be extensively 'flushed' by $\mathrm{CO}_{2}$ as gas segregates to the reservoir roof, giving rise to the persistent summit $\mathrm{CO}_{2}$ gas plume ${ }^{31}$. Fissure eruptions, which commonly take place inside the caldera, are generated from inherently volatilerich melts that, in some cases, may have been stored for slightly longer at shallow depths, undergoing greater fractionation, but still have enough vapour associated with them to be more buoyant and erupt explosively. It is common for eruptions to transition from fissure-type to high fountaining, controlled essentially by the plumbing system. In these cases there is no geochemical difference between the two styles, and this is consistent with the statistical data (Supplementary Table 4).

\section{The volatile composition of primitive melts}

We can estimate volatile concentrations in the 'depleted' and 'enriched' primitive melts based on the concentrations of $\mathrm{Nb}$ and Ce in the melt inclusions, on the basis that the partition coefficients for these elements are similar to $\mathrm{CO}_{2}$ and $\mathrm{H}_{2} \mathrm{O}$ respectively, during melting ${ }^{6,9,32}$. Degassing of $\mathrm{H}_{2} \mathrm{O}$ and $\mathrm{CO}_{2}$ from the melt inclusions will lower $\mathrm{H}_{2} \mathrm{O} / \mathrm{Ce}$ and $\mathrm{CO}_{2} / \mathrm{Nb}$. There are three examples in the literature where the $\mathrm{CO}_{2} / \mathrm{Nb}$ ratio of undegassed melts has been quantified ${ }^{29,33,34}$. The $\mathrm{CO}_{2} / \mathrm{Nb}$ ratios from these studies range from $239 \pm 46$ (for depleted melts from the Siqueiros transform fault on the East Pacific Rise ${ }^{29}$ ), $314 \pm 125$ (for melt inclusions from Borgarhraun, northern Iceland ${ }^{34}$ ) and mean values of 537 and 724 (from measurement of both dissolved and vesicle carbon in samples from the Mid-Atlantic Ridge at $14^{\circ} \mathrm{N}$ and $34^{\circ} \mathrm{N}$ respectively, which include the 'popping rocks' ${ }^{33,35}$ ). Reported $\mathrm{CO}_{2} / \mathrm{Nb}$ ratios may therefore vary by at least a factor of three. A study of volatiles and trace elements of Lo'ihi samples quantified bulk (dissolved and vesicle) $\mathrm{CO}_{2}$, as well as $\mathrm{Nb}$ (ref. 6). Bulk $\mathrm{CO}_{2}$ in these samples reached a maximum of $0.63 \mathrm{wt} \%$ (ref. 6). The $\mathrm{Nb}$ content of the samples ranged from 11 to 17 p.p.m., yielding a potential undegassed $\mathrm{CO}_{2} / \mathrm{Nb}$ of 350-570. Given the geochemical heterogeneity in our samples it is likely that the $\mathrm{CO}_{2} / \mathrm{Nb}$ ratio of the undegassed melts was also variable. The $\mathrm{CO}_{2} / \mathrm{Nb}$ ratios of the Kilauea melt inclusions are 2-68 (Supplementary Fig. 6). The melt inclusions have undergone significant depletion of $\mathrm{CO}_{2}$ before (by degassing) and/or after (by partitioning into a shrinkage bubble) entrapment. After normalizing the melt compositions to $15 \mathrm{wt} \% \mathrm{MgO}$ (using 


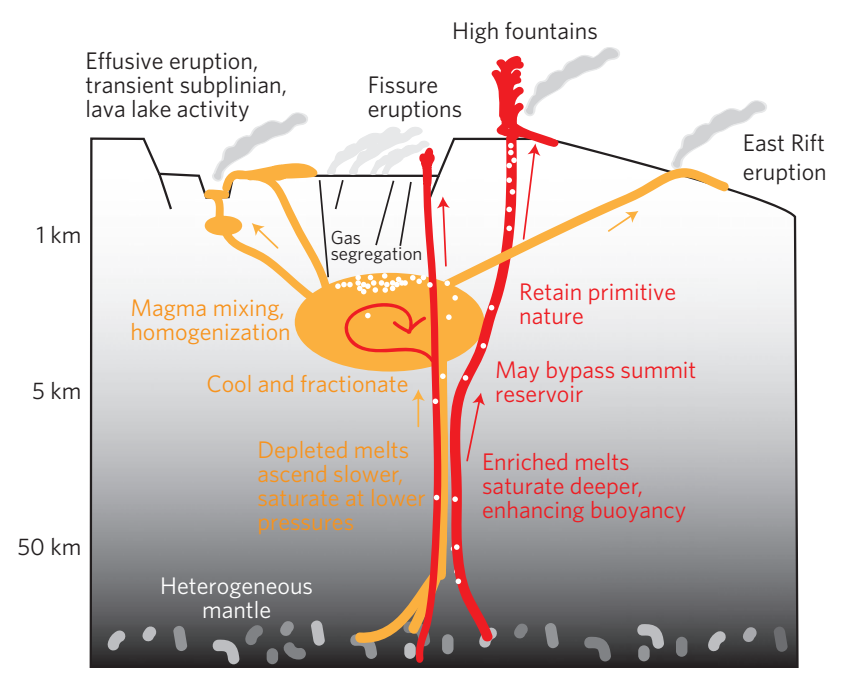

Figure 4 | Schematic diagram to show how primary melt compositions may be linked to eruption style. Sustained explosive forms of eruption are driven, on average, by enriched, volatile-rich melts from depth, which retain their primitive nature and bypass the summit magma reservoir. This may occur if the magma reservoir acts as a 'density filter', focusing denser buoyant melts around it. Effusive and transient explosive styles of eruption are fed by more depleted, magmas that have mixed efficiently in the magma reservoir. These are generalizations gleaned from a large population of data, which show a spread of compositions within each eruption style class.

Petrolog3 (ref. 36); see Supplementary Data) and using a $\mathrm{CO}_{2} / \mathrm{Nb}$ ratio of $314 \pm 125$ (ref. 34), we estimate that primitive melt $\mathrm{CO}_{2}$ concentrations may have ranged between $0.17( \pm 0.07)$ and 0.68 $( \pm 0.27) \mathrm{wt} \%$ over the past 600 years (Supplementary Data), which encompasses the estimate derived from magma supply rate and gas flux measurements (0.7 wt\% (ref. 31); Fig. 1b). We acknowledge significant uncertainty associated with these ranges, as the range in $\mathrm{CO}_{2} / \mathrm{Nb}$ for primitive undegassed Killauea melts is not known precisely. If, for example, the maximum $\mathrm{CO}_{2} / \mathrm{Nb}$ ratio was more similar to 724 , the mean value for the Mid-Atlantic Ridge at $34^{\circ} \mathrm{N}$ (ref. 33) (we regard this as an extreme value), these estimates would become $0.39-1.6 \mathrm{wt} \% \mathrm{CO}_{2}$. This range still encompasses the $\mathrm{CO}_{2}$ content of primary magmas estimated from volcanic gas fluxes ${ }^{31}$.

The $\mathrm{H}_{2} \mathrm{O} / \mathrm{Ce}$ ratios in the melts are better understood, owing to the frequent occurrence of undegassed (with respect to $\mathrm{H}_{2} \mathrm{O}$ ) melts to examine $e^{6,32,37}$. In the melt inclusions presented here, $\mathrm{H}_{2} \mathrm{O} / \mathrm{Ce}$ ratios range from 18 to 315 , the highest values (mostly fountain and fissure samples from the twentieth century) far exceeding the range observed in submarine glasses from Hawai'i (349 for South Arch glasses $^{9}$ and 182 for a high-Mg Kilauea glass ${ }^{6}$ ); this indicates that some melts may be inherently enriched in $\mathrm{H}_{2} \mathrm{O}$ owing to a change in mantle source composition. Using the relationship between $\mathrm{Pb}$ isotope composition and $\mathrm{H}_{2} \mathrm{O} / \mathrm{Ce}$ for Loihi melts ${ }^{6}$ and the range in $\mathrm{Pb}$ isotopes in lavas erupted over the historical period at Kilauea ${ }^{3}$, we can estimate that the $\mathrm{H}_{2} \mathrm{O} / \mathrm{Ce}$ ratio for primitive melts lies in the range 150-200, giving rise to primitive melt compositions of 0.27 $0.80 \mathrm{wt} \% \mathrm{H}_{2} \mathrm{O}$, higher and more variable than, but encompassing, previous estimates ${ }^{16,19,38,39}$. We propose that the more volatile-rich melts are those that statistically are more likely to bypass the summit magma reservoir, retain their primitive composition, and ultimately drive explosive high-fountaining eruptions.

\section{Temporal trends in melt composition and eruption style}

The matrix glass and inclusion compositions change coherently through time (Fig. 1b,c), similar to the whole-rock data ${ }^{3}$. Matrix glass compositions are relatively uniform from 1500 to the early nineteenth century, after which the abundance of incompatible minor elements $\left(\mathrm{K}_{2} \mathrm{O}, \mathrm{P}_{2} \mathrm{O}_{5}, \mathrm{TiO}_{2}\right)$ and $\mathrm{La} / \mathrm{Yb}$ and $\mathrm{Nb} / \mathrm{Y}$ increase (Fig. 1b) until the 1959 Kilauea Iki eruption. Subsequent eruptions (between 1961 and 2010) have decreasing incompatible element concentrations and decreasing $\mathrm{La} / \mathrm{Yb}$ and $\mathrm{Nb} / \mathrm{Y}$ (Fig. 1b). These trends are similar to those observed in the whole-rock compositions ${ }^{3,5}$, although the matrix glass compositions have a larger degree of compositional variation. The melt inclusion trends mimic those of the matrix glasses but are less distinct, owing to the larger range of compositions for each eruption. As for eruption style, a similar statistical approach may be used to examine the differences between the temporal groups (Supplementary Fig. 7). The twentieth-century melts (erupted 1919-1982) are statistically more primitive, more enriched in highly incompatible elements and preserve higher volatile concentrations than melts erupted during any other period. The pre- AD 1500 and twenty-first century melts are compositionally similar, with no statistical difference in their $\mathrm{La} / \mathrm{Yb}$ ratios. These eruptions are volatile-poor and significantly more evolved than those produced during the intervening eruptions. The nineteenth-century melts have an intermediate $\mathrm{La} / \mathrm{Yb}$ and $\mathrm{Nb} / \mathrm{Y}$ signature but are volatile-poor.

Our results for melt inclusions, in addition to changes in wholerock isotopic compositions and trace element ratios ${ }^{3}$, suggest the source region for melting at Kilauea is heterogeneous ${ }^{3-5}$ on short spatial scales. Coupled with the variability in source composition may be changes in the degree of partial melting. Modelling using whole-rock data ${ }^{3}$ suggests that the degree of melting may have halved from the early nineteenth to mid-twentieth century, correlating with a period of lower magma supply rate ${ }^{3}$. Subsequently, the degree of partial melting and magma supply rate may have increased between the mid and late-twentieth century ${ }^{3}$.

Most of the sampled high-fountaining events occurred during the twentieth century, many of the intermediate-enriched fissure products sampled formed during the nineteenth and twentieth centuries, and most of the twenty-first-century eruptions were transient explosive events involving volatile-poor, relatively evolved melts. It is important to note that not all high-fountaining eruptions occurred in the twentieth century, and others, such as the reticuliteproducing fountains immediately after caldera formation in about $\mathrm{AD} 1550$, are not as compositionally enriched as melts associated with fissure eruptions during the twentieth century. Nonetheless, the overall populations define distinct geochemical trends that suggest that eruptive styles at Kilauea are dictated not only by tectonic structure, stress field and shallow magmatic processes ${ }^{40}$ but also by changes in primitive melt geochemistry, linked to the degree of melting and the composition of the mantle on the timescales of years to decades.

\section{Methods}

Deposits from 25 eruptions were sampled from the summit region and both rift zones (Fig. 1a and Supplementary Table 1). The samples were classified according to eruption style by careful study of the deposit characteristics and where observational accounts of the eruptions exist, by the character of the eruption that produced them (Table 1). Olivines were picked and mounted, ground and polished to expose the melt inclusions. The inclusions were analysed using secondary-ion mass spectrometry for carbon dioxide and water concentrations, and by electron microprobe for major, minor and the volatiles sulphur chlorine and fluorine, and by laser ablation inductively coupled plasma mass spectrometry for trace elements. Host olivines were analysed for their major element composition by electron microprobe (Supplementary Methods for details of the analytical methods). Melt inclusion compositions were corrected for PEC and Fe loss using the Petrolog3 software ${ }^{41}$, requiring on average $<10 \%$ olivine addition ${ }^{41}$ (Supplementary Methods for details of the correction procedure). Samples have $10-20 \mathrm{vol} \%$ olivine $0.5-2.0 \mathrm{~mm}$ in size, containing inclusions of pale brown glass up to $300 \mu \mathrm{m}$ in diameter and clusters of small elliptical fluid inclusions. Melt inclusions that were fractured, necked or contained $>5$ vol\% oxides were discarded. Vapour bubbles exist in 116 of the 374 melt inclusions analysed (most occupying $<7$ vol\% of the inclusion). 
Received 12 May 2013; accepted 14 March 2014; published online XX Month XXXX

\section{References}

1. Head, J. W. \& Wilson, L. Lava fountain heights at Pu'u 'O'o, Kìlauea, Hawaii: Indicators of amount and variations of exsolved magma volatiles. J. Geophys. Res. 92, 13715-13719 (1987)

2. Jaupart, C. \& Vergniolle, S. Laboratory models of Hawaiian and Strombolian eruptions. Nature 331, 58-60 (1988).

3. Pietruszka, A. J. \& Garcia, M. O. A rapid fluctuation in the mantle source and melting history of Kilauea Volcano inferred from the geochemistry of its historical summit lavas (1790-1982). J. Petrol. 40, 1321-1342 (1999).

4. Garcia, M. O., Pietruszka, A. J. \& Rhodes, J. M. A petrologic perspective of Kilauea Volcano's summit magma reservoir. J. Petrol. 44, 2313-2339 (2003)

5. Marske, J. P., Garcia, M. O., Pietruszka, A. J., Rhodes, J. M. \& Norman, M. D. Geochemical variations during Kīlauea's Pu'u 'Ō'ō eruption reveal a fine-scale mixture of mantle heterogeneities within the hawaiian plume. J. Petrol. 49, 1297-1318 (2008).

6. Dixon, J. E. \& Clague, D. A. Volatiles in basaltic glasses from loihi seamount, Hawaii: evidence for a relatively dry plume component. J. Petrol. 42, 627-654 (2001).

7. Hauri, E. H. Major-element variability in the Hawaiian mantle plume. Nature 382, 415-419 (1996)

8. Lassiter, J. \& Hauri, E. Osmium-isotope variations in Hawaiian lavas: Evidence for recycled oceanic lithosphere in the Hawaiian plume. Earth Planet. Sci. Lett. 164, 483-496 (1998)

9. Dixon, J. E., Clague, D. A., Wallace, P. \& Poreda, R. Volatiles in alkalic basalts form the North Arch Volcanic Field, Hawaii: Extensive degassing of deep submarine-erupted alkalic series lavas. J. Petrol. 38, 911-939 (1997).

10. Anderson, A. T. $\mathrm{CO}_{2}$ and the eruptibility of picrite and komatiite. Lithos $\mathbf{3 4}$, 19-25 (1995).

11. Helz, R. T. Magmatic Processes: Physicochemical Principles 241-258 (1987).

12. Costa, F. \& Dungan, M. Short time scales of magmatic assimilation from diffusion modeling of multiple elements in olivine. Geology 33, $837-840$ (2005)

13. Harris, D. M. \& Anderson, A. T. Concentrations, sources, and losses of $\mathrm{H}_{2} \mathrm{O}$, $\mathrm{CO}_{2}$, and $\mathrm{S}$ in Kilauean basalt. Geochim. Cosmochim. Acta 47, 1139-1150 (1983)

14. Anderson, A. T. \& Brown, G. G. $\mathrm{CO}_{2}$ contents and formation pressures of some Kilauean melt inclusions. Am. Mineral. 78, 794-803 (1993).

15. Wallace, P. J. \& Anderson, A. T. Effects of eruption and lava drainback on the $\mathrm{H}_{2} \mathrm{O}$ contents of basaltic magmas at Kilauea Volcano. Bull. Volcanol. 59, 327-344 (1998).

16. Hauri, E. SIMS analysis of volatiles in silicate glasses, 2: Isotopes and abundances in Hawaiian melt inclusions. Chem. Geol. 183, 115-141 (2002).

17. Newman, S. \& Lowenstern, J. B. VolatileCalc: A silicate melt- $\mathrm{H}_{2} \mathrm{O}-\mathrm{CO}_{2}$ solution model written in visual basic for excel. Comput. Geosci. 28, 597-604 (2002).

18. Gerlach, T. M. \& Graeber, E. J. Volatile budget of Kïlauea volcano. Nature 313, 273-277 (1985)

19. Dixon, J. E., Clague, D. A. \& Stolper, E. M. Degassing history of water, sulfur, and carbon in submarine lavas from Kïlauea Volcano, Hawaii. J. Geol. 371-394 (1991)

20. Garcia, M. O., Muenow, D. W., Aggrey, K. E. \& O’Neil, J. R. Major element, volatile, and stable isotope geochemistry of Hawaiian submarine tholeiitic glasses. J. Geophy. Res. 94, 10525-10538 (1989).

21. Kent, A. J. R. et al. Widespread assimilation of a seawater-derived component at Loihi Seamount, Hawaii. Geochim. Cosmochim. Acta 63, 2749-2761 (1999).

22. Sobolev, A. Melt inclusions in minerals as a source of principle petrological information. Petrology 4, 209-220 (1996).

23. Maclennan, J. Concurrent mixing and cooling of melts under Iceland. J. Petrol. 49, 1931-1953 (2008)

24. Kent, A. J. \& Elliott, T. R. Melt inclusions from Marianas arc lavas: Implications for the composition and formation of island arc magmas. Chem. Geol. 183, 263-286 (2002)

25. Dixon, J. E. Degassing of alkalic basalts. Am. Mineral. 82, 368-378 (1997).
26. Steele-Macinnis, M., Esposito, R. \& Bodnar, R. J. Thermodynamic model for the effect of post-entrapment crystallization on the $\mathrm{H}_{2} \mathrm{O}-\mathrm{CO}_{2}$ systematics of vapor-saturated, silicate melt inclusions. J. Petrol. 52, 2461-2482 (2011).

27. Lloyd, A. S. et al. Volatile loss from melt inclusions in pyroclasts of differing sizes. Contr. Mineral. Petrol. 165, 129-153 (2013).

28. Gaetani, G. A., O’Leary, J. A., Shimizu, N., Bucholz, C. E. \& Newville, M. Rapid reequilibration of $\mathrm{H}_{2} \mathrm{O}$ and oxygen fugacity in olivine-hosted melt inclusions. Geology 40, 915-918 (2012).

29. Saal, A. E., Hauri, E. H., Langmuir, C. H. \& Perfit, M. R. Vapour undersaturation in primitive mid-ocean-ridge basalt and the volatile content of Earth's upper mantle. Nature 419, 451-455 (2002).

30. Roggensack, K., Hervig, R. L., McKnight, S. B. \& Williams, S. N. Explosive basaltic volcanism from Cerro Negro volcano: influence of volatiles on eruptive style. Science 277, 1639-1642 (1997).

31. Gerlach, T. M., McGee, K. A., Elias, T., Sutton, A. J. \& Doukas, M. P. Carbon dioxide emission rate of Kilauea Volcano: Implications for primary magma and the summit reservoir. J. Geophy. Res. 107, 2189 (2002)

32. Danyushevsky, L. V., Eggins, S. M., Falloon, T. J. \& Christie, D. M. $\mathrm{H}_{2} \mathrm{O}$ abundance in depleted to moderately enriched mid-ocean ridge magmas; Part I: Incompatible behaviour, implications for mantle storage, and origin of regional variations. J. Petrol. 41, 1329-1364 (2000).

33. Cartigny, P., Pineau, F., Aubaud, C. \& Javoy, M. Towards a consistent mantle carbon flux estimate: Insights from volatile systematics $\left(\mathrm{H}_{2} \mathrm{O} / \mathrm{Ce}, \delta \mathrm{D}\right.$, $\left.\mathrm{CO}_{2} / \mathrm{Nb}\right)$ in the North Atlantic mantle $\left(14^{\circ} \mathrm{N}\right.$ and $\left.34^{\circ} \mathrm{N}\right)$. Earth Planet. Sci. Lett. 265, 672-685 (2008).

34. Hauri, E., Gronvold, K., Oskarsson, N. \& McKenzie, D. AGU Spring Meeting Abstracts. 03.

35. Sarda, P. \& Graham, D. Mid-ocean ridge popping rocks: Implications for degassing at ridge crests. Earth Planet. Sci. Lett. 97, 268-289 (1990).

36. Danyushevsky, L. V., Della-Pasqua, F. N. \& Sokolov, S. Re-equilibration of melt inclusions trapped by magnesian olivine phenocrysts from subduction-related magmas: Petrological implications. Contrib. Mineral. Petrol. 138, 68-83 (2000).

37. Dixon, J. E., Stolper, E. \& Delaney, J. R. Infrared spectroscopic measurements of $\mathrm{CO}_{2}$ and $\mathrm{H}_{2} \mathrm{O}$ in Juan de Fuca Ridge basaltic glasses. Earth Planet. Sci. Lett. 90 87-104 (1988).

38. Wallace, P. J. Water and partial melting in mantle plumes: Inferences from the dissolved $\mathrm{H}_{2} \mathrm{O}$ concentrations of Hawaiian basaltic magmas. Geophys. Res. Lett. 25, 3639-3642 (1998)

39. Clague, D. A., Weber, W. S. \& Dixon, J. E. Picritic glasses from Hawaii. Nature 353, 553-556 (1991).

40. Ryan, M. P. The mechanics and three-dimensional internal structure of active magmatic systems: Kilauea Volcano, Hawaii. J. Geophys. Res. 93, 4213-4248 (1988).

41. Danyushevsky, L. V. \& Plechov, P. Petrolog3: Integrated software for modeling crystallization processes. Geochem. Geophys. Geosys. 12, Q07021 (2011).

\section{Acknowledgements}

We thank D. Clague for advice and comments on our manuscript, which improved it immensely. This work was financially supported by the Natural Environment Research Council (NERC), UK: I.R.S. acknowledges a NERC studentship. M.E. acknowledges a NERC urgency grant NE/G001537/1 and a NERC ion probe facility grant IMF376/0509. I.S. acknowledges a USGS Jack Kleinman Grant for Volcano Research. We thank J. Kauahikaua and the staff of the Hawaiian Volcano Observatory for allowing us access and providing logistical support for our fieldwork. In Edinburgh, R. Hinton and C-J. de Hoog assisted with the ion probe measurements. In Cambridge, J. Day, C. Petrone, M. Walker and I. Buisman assisted with sample preparation and analysis.

\section{Author contributions}

I.R.S., D.A.S. and B.F.H. collected the samples. I.R.S. prepared and analysed the samples. All authors contributed to data interpretation.

\section{Additional information}

Supplementary information is available in the online version of the paper. Reprints and permissions information is available online at www.nature.com/reprints.

Correspondence and requests for materials should be addressed to M.E.

\section{Competing financial interests}

The authors declare no competing financial interests. 